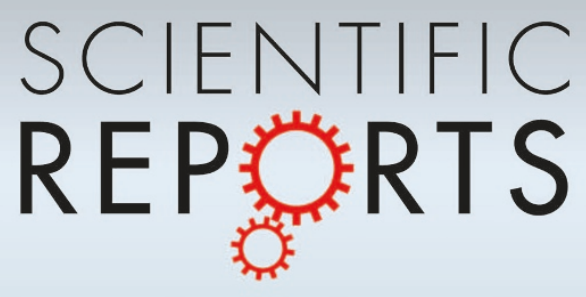

\title{
OPEN A meta-analysis of olanzapine for the \\ prevention of chemotherapy-induced nausea and vomiting
}

SUBJECT AREAS:

DRUG REGULATION

HEALTH SCIENCES

IRRITABLE BOWEL SYNDROME

Received

3 February 2014

Accepted

4 April 2014

Published

28 April 2014

Correspondence and requests for materials should be addressed to

B.L.G. (yshu7661@

sina.com) or B.H.H.

(xkyyhan@gmail.com)

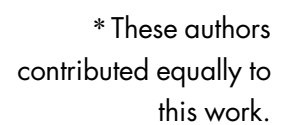

\author{
Xiao-fei Wang ${ }^{1,2 *}$, Yun Feng ${ }^{1 *}$, Ying Chen ${ }^{3}$, Bei Li Gao' \& Bao-hui Han ${ }^{2}$
}

\begin{abstract}
'Department of pulmonary Medicine, Ruijin Hospital, School of Medicine, Shanghai Jiao Tong University, 200025, Shanghai, China, ${ }^{2}$ Department of pulmonary Medicine, Shanghai Chest Hospital, Shanghai Jiao Tong University, 200030, Shanghai, China, ${ }^{3}$ Department of Emergency Medicine, Ruijin Hospital, School of Medicine, Shanghai Jiao Tong University, 200025, Shanghai, China.
\end{abstract}

Chemotherapy-induced nausea and vomiting (CINV) is associated with a significant deterioration in quality of life and is one of the reasons for the discontinuation of treatment. Olanzapine is known as an atypical antipsychotic agent, but it has been reported to be effective in treating refractory CINV due to its broad and potent inhibitory activity at multiple receptors involved in the nausea and vomiting pathways. This study was conducted to assess the efficacy of olanzapine for the prevention of CINV after moderately or highly emetogenic chemotherapy. After a search of Medline (Ovid), PubMed, CNKI, Wanfang and Weipu from 1990 to October 2013, all randomised controlled trials of olanzapine for the prevention of CINV were included in this study. The meta-analysis was performed using RevMan 5.0.19 software. 6 studies involving 726 total patients were included, of which 441 were Chinese oncology patients. We found that for both general populations and Chinese populations, antiemetic regimens including olanzapine are more effective at reducing CINV than regimens that do not include olanzapine, especially in the delayed phase of CINV. and non-response to treatment ${ }^{2}$. Nausea and vomiting are classified as acute $(<24 \mathrm{~h}$ post-chemotherapy $)$ or delayed (24-120 h post-chemotherapy) according to the time of occurrence. CINV symptoms may occur despite the optimal use of appropriate prophylaxis ${ }^{3}$. The principal neurotransmitters that drive CINV in all forms are serotonin, dopamine, acetylcholine, and substance $\mathrm{P}^{4}$. Recommendations for the prevention of CINV include 5HT3-serotonin antagonists, glucocorticoids, substance P/neurokinin-1 antagonists, and D2-dopamine antagonists, such as phenothiazines or butyrophenones, depending upon the emetogenicity of the chemotherapy regimen and patient-specific factors. However, other subtypes of serotonin and dopamine receptors have been implicated in the pathophysiology of CINV, which may explain the phenomenon of refractory CINV despite the appropriate use of the prophylactic drugs cited above $e^{5}$.

The ideal antiemetic for refractory CINV is a pharmacologic agent that blocks a variety of serotonin and dopamine receptor subclasses, in addition to muscarinic and histaminergic receptors, all of which have been implicated in or theorised to contribute to CINV; such an agent should be administered once daily with few adverse reactions. Known as an atypical antipsychotic agent of the thiobenzo-diazepine class, olanzapine was approved by the USA FDA (Food and Drug Administration) for the treatment of the manifestations of psychotic disorders in $1996^{6}$. Olanzapine blocks multiple neurotransmitter receptors including dopaminergic D1, D2, D3, D4 brain receptors, serotonergic 5-HT2a, 5-HT2c, 5-HT3, 5-HT6 receptors, catecholamine alpha1 adrenergic receptors, acetylcholine muscarinic receptors, and histamine $\mathrm{H} 1$ receptors ${ }^{7}$. Moreover, olanzapine may reduce opioid requirements in cancer patients with uncontrolled pain, cognitive impairment, or anxiety ${ }^{8}$. Due to the broad and potent inhibitory activity of olanzapine at multiple receptors involved in the nausea and vomiting pathways, this agent is an effective treatment for refractory CINV.

\section{Results}

Search results. Based on our search strategy, the primary screening produced 13 potentially relevant articles, of which 6 met the inclusion criteria as an attempt to evaluate the efficacy of olanzapine for the prevention of 
vomiting and nausea induced by moderately or highly emetogenic chemotherapy. (Mizukami N et al. 2013'; Navari RM et al. 2011 ${ }^{10}$; Tan L et al.2009 ${ }^{11}$; X Wang et al. 2012 ${ }^{12}$; WK Mao et al. 2011 ${ }^{13}$; YL Lv et al. $2013^{14}$ ). All articles were fully published. The detailed selection process is presented in Figure 1.

Study characteristics. The baseline characteristics of the qualified studies are presented in Table 1. Five studies compared a regimen including olanzapine to a standard regimen. The following characteristics were found regarding the standard antiemetic regimen: 1 study used corticosteroids, a 5-HT3 receptor antagonist and a NK-1 receptor antagonist; 2 studies used corticosteroids and a 5-HT3 receptor antagonist; 1 study used only a 5-HT3 receptor antagonist; 1 study used diphenhydramine + corticosteroids + a 5-HT3 receptor antagonist; and 1 study compared olanzapine versus aprepitant for the prevention of CINV with corticosteroids and a 5-HT3 receptor antagonist. In addition, 4 studies included patients who underwent moderately to highly emetogenic chemotherapy, while 2 studies specified only highly emetogenic chemotherapy. 4 studies evaluated olanzapine's effect separately in the acute, delayed and overall phase. 1 study provided only overall data, whereas 1 study lacked overall data. All studies were blinded. All six studies defined complete response to antiemetic therapy as no vomiting and no use of rescue therapy, which allows us to conclude that it is reasonable to combine the six studies in a meta-analysis using a fixed-effects model.

Efficacy. In the 5 individual studies with subgroup staging data, the cumulative incidence of complete response was significantly increased in the olanzapine-containing groups on the first day of chemotherapy [Odds Ratio $(\mathrm{OR})=1.95,95 \%$ confidence interval (CI) $1.17-3.23, p=0.01$, Figure 2A]. Similar results were also obtained for delayed vomiting induced by highly or moderately emetogenic chemotherapy $(\mathrm{OR}=2.65,95 \% \mathrm{CI} 1.36-5.15, \mathrm{p}=$ 0.004 , Figure 2B). Overall, when the 5 studies were combined, the relative risk of a complete response was 4.07 (95\% CI 1.59-10.43,
Figure 2C). This combined relative risk is again significantly greater than that of standard therapy $(\mathrm{p}=0.003)$, indicating that patients are more likely to experience a complete response to an olanzapine regimen than to a regimen without olanzapine.

Olanzapine also showed superior anti-nausea effects compared with non-olanzapine regimens in the delayed phase $(\mathrm{OR}=2.79$, $95 \%$ CI 1.76-4.43, $\mathrm{p}=0.0001$, Figure $3 \mathrm{~B}$ ) and the overall phase $(\mathrm{OR}=3.40,95 \%$ CI 2.31-5.00, $\mathrm{p}=0.00001$, Figure 3C). However, olanzapine did not show any superiority in the acute phase $(\mathrm{RR}=$ $1.34,95 \%$ CI $0.77-2.34, \mathrm{p}=0.30$, Figure $3 \mathrm{~A}$ ) compared with nonolanzapine regimens.

Subgroup analyses. When only Chinese studies were included in the analysis, the overall risk of experiencing a complete response on the olanzapine regimen relative to the standard regimen ranged from 2.96 to $8.96(\mathrm{OR}=5.15, \mathrm{p}=0.00001$, Table 2$)$. While the relative risk of a complete response was greater than non-olanzapine regimens in all 3 studies, the difference reached statistical significance only in the delayed phase $(p=0.00001)$ but not in the acute phase $(p=0.07)$. This might be due to the low incidence of emesis during the acute phase, which reduces the power of the study to demonstrate statistical significance. Regarding nausea control, we did not find that an olanzapine regimen was better than a standard regimen, in neither the acute phase nor the delayed phase (Table 2).

When the study that compared olanzapine versus aprepitant for the prevention of CINV was excluded, no great difference was observed among the combined studies. The olanzapine regimens were more effective at preventing emesis in the acute phase $(\mathrm{OR}=$ $2.39,95 \%$ CI $1.10-5.22, \mathrm{p}=0.03$, Table 2$)$, delayed phase $(\mathrm{OR}=$ $3.24,95 \%$ CI $2.08-5.04, \mathrm{p}=0.00001$, Table 2$)$ and overall phase (OR $=5.38,95 \%$ CI $3.14-9.20, \mathrm{p}=0.00001$, Table 2$)$. The only difference was that no statistical evidence in favour of an olanzapine regimen in nausea control was demonstrated, even in the delayed phase $(\mathrm{OR}=$ $2.54,95 \%$ CI 1.01-6.42, $\mathrm{p}=0.05$, Table 2), which might be due to the smaller number of patients in these groups.

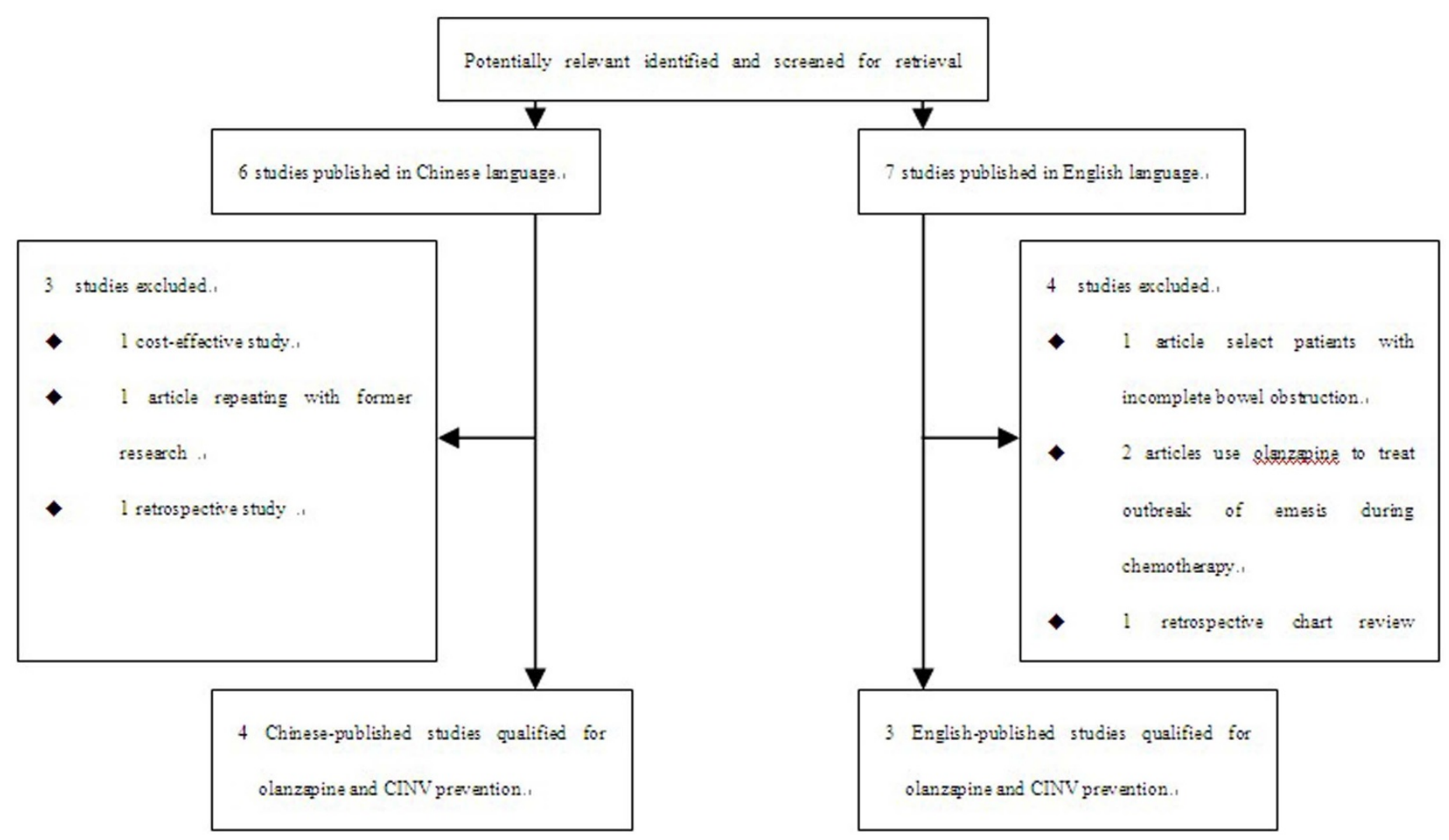

Figure 1 | Flow diagram of search strategy and study selection. 


\begin{tabular}{|c|c|c|c|c|c|c|c|c|}
\hline \multirow[b]{2}{*}{ Study } & \multirow[b]{2}{*}{ Ethnicity } & \multirow[b]{2}{*}{ control } & \multirow[b]{2}{*}{ Period } & \multicolumn{2}{|c|}{ OL group } & \multicolumn{2}{|c|}{ control group } & \multirow[b]{2}{*}{ Characteristics } \\
\hline & & & & CR & all & CR & all & \\
\hline $\begin{array}{l}\text { Mizukami } \mathrm{N} \text { et al. } \\
2013\end{array}$ & Japanese & Vomiting control & $\begin{array}{l}\text { Acute } \\
\text { Delayed } \\
\text { Overall }\end{array}$ & $\begin{array}{l}22 \\
22 \\
22\end{array}$ & $\begin{array}{l}22 \\
22 \\
22\end{array}$ & $\begin{array}{l}19 \\
16 \\
15\end{array}$ & $\begin{array}{l}22 \\
22 \\
22\end{array}$ & $\begin{array}{l}\text { Moderately or highly emetogenic } \\
\text { chemotherapy } \\
\text { C: corticosteroid + 5-HT3receptor } \\
\text { antagonist + NK-1 receptor antagonist } \\
\text { O: C regimen + O } 5 \mathrm{mg} / \text { d days } 0-4\end{array}$ \\
\hline $\begin{array}{l}\text { Navari RM et al. } \\
2011\end{array}$ & American & Nausea control & $\begin{array}{l}\text { Acute } \\
\text { Delayed } \\
\text { Overall } \\
\text { Acute } \\
\text { Delayed } \\
\text { Overall }\end{array}$ & $\begin{array}{l}97 \\
77 \\
77 \\
87 \\
69 \\
69\end{array}$ & $\begin{array}{l}121 \\
121 \\
121 \\
121 \\
121 \\
121\end{array}$ & $\begin{array}{l}87 \\
73 \\
73 \\
87 \\
38 \\
38\end{array}$ & $\begin{array}{l}120 \\
120 \\
120 \\
120 \\
120 \\
120\end{array}$ & $\begin{array}{l}\text { Highly emetogenic chemotherapy } \\
\text { C: corticosteroid + 5-HT3 receptor } \\
\text { antagonist + NK-1 receptor antagonist } \\
\text { O: C regimen + O } 10 \mathrm{mg} / \text { d days } 1-4\end{array}$ \\
\hline Tan L et al. 2009 & Chinese & Nausea control & $\begin{array}{l}\text { Acute } \\
\text { Delayed } \\
\text { Overall } \\
\text { Acute } \\
\text { Delayed } \\
\text { Overall }\end{array}$ & $\begin{array}{r}114 \\
102 \\
102 \\
117 \\
93 \\
93\end{array}$ & $\begin{array}{l}121 \\
121 \\
121 \\
121 \\
121 \\
121\end{array}$ & $\begin{array}{r}101 \\
73 \\
63 \\
98 \\
50 \\
48\end{array}$ & $\begin{array}{l}108 \\
108 \\
108 \\
108 \\
108 \\
108\end{array}$ & $\begin{array}{l}\text { Moderately or highly emetogenic } \\
\text { chemotherapy } \\
\text { C:corticosteroid + } 5 \text {-HT3 receptor } \\
\text { antagonist } \\
\text { O: C regimen + } 10 \mathrm{mg} / \mathrm{d} \text { days } 1-5\end{array}$ \\
\hline $\begin{array}{l}\text { WK Mao et al. } \\
2011\end{array}$ & Chinese & Vomiting control & $\begin{array}{l}\text { Acute } \\
\text { Delayed } \\
\text { Overall }\end{array}$ & $\begin{array}{l}45 \\
39 \\
38\end{array}$ & $\begin{array}{l}46 \\
46 \\
46\end{array}$ & $\begin{array}{l}38 \\
23 \\
15\end{array}$ & $\begin{array}{l}46 \\
46 \\
46\end{array}$ & $\begin{array}{l}\text { Moderately or highly emetogenic } \\
\text { chemotherapy } \\
\text { C: corticosteroid + } 5 \text {-HT3 receptor } \\
\text { antagonist } \\
\text { O: C regimen + O } 10 \mathrm{mg} / \mathrm{d} \text { days non } \\
\text { unspecified }\end{array}$ \\
\hline $\begin{array}{l}X \text { Wang et al. } \\
2012\end{array}$ & Chinese & $\begin{array}{l}\text { Vomiting control } \\
\text { Nausea control }\end{array}$ & $\begin{array}{l}\text { Acute } \\
\text { Delayed } \\
\text { Acute } \\
\text { Delayed }\end{array}$ & $\begin{array}{l}40 \\
46 \\
46 \\
49\end{array}$ & $\begin{array}{l}60 \\
60 \\
60 \\
60\end{array}$ & $\begin{array}{l}27 \\
32 \\
42 \\
45\end{array}$ & $\begin{array}{l}60 \\
60 \\
60 \\
60\end{array}$ & $\begin{array}{l}\text { Highly emetogenic chemotherapy } \\
\text { C: } 5 \text {-HT3 receptor antagonist } \\
\text { O: C regimen + O } 10 \mathrm{mg} / \mathrm{d} \text { days } 1-8\end{array}$ \\
\hline $\begin{array}{l}\text { YL Lv et al. } \\
2013\end{array}$ & Chinese & Vomiting control & Overall & 22 & 30 & 11 & 30 & $\begin{array}{l}\text { Moderately or highly emetogenic } \\
\text { chemotherapy } \\
\text { C: diphenhydramine + corticosteroid + 5- } \\
\text { HT3 receptor antagonist } \\
\text { O: C regimen + O } 5 \mathrm{mg} / \text { d days } 1\end{array}$ \\
\hline
\end{tabular}

\section{Discussion}

Olanzapine was first found to be effective in the prevention and treatment of nausea in a palliative care setting and in patients with opioid-induced nausea according to some case reports ${ }^{15,16}$. A patient with leukaemia reported a significant improvement in chronic nausea with the use of olanzapine ${ }^{17}$, and in 6 patients receiving palliative care, olanzapine showed a potential use in the control of intractable nausea due to opioids, neoplasm, and/or medications ${ }^{18}$. A retrospective chart review also found that olanzapine may decrease delayed emesis in patients following moderate to highly emetogenic chemotherapy ${ }^{19}$.

Based on the clinical observations and its mechanism of action of blocking multiple neurotransmitter receptors, olanzapine is believed to be effective in the prevention and treatment of vomiting and nausea induced by chemotherapy. It can be administered once daily due to its long half-life, which would improve patient compliance. Another benefit is that it is not a cytochrome P450 inhibitor and would not interact with other drugs ${ }^{7}$.

A phase I study was designed to evaluate the maximum tolerated dose of olanzapine as an anti-emetic by utilising a 4-cohort dose escalation of 3-6 patients per cohort ${ }^{20}$. The result was $5 \mathrm{mg}$ (for days -2 and -1 ) and $10 \mathrm{mg}$ (for days $0-7$ ).

Phase II and III studies using the dose of olanzapine in the previously described phase I trial were meta-analysed. We found that a higher rate of CR can be achieved when olanzapine was added to the standard regimen. The anti-emetic effect of Olanzapine was more significant for delayed CINV, in both the genreal populations and the Chinese populations. Several studies evaluated the anti-nausea effect of olanzapine; we also found that olanzapine-containing regimens achieved better nausea control in the delayed phase and the overall phase. Based on these data, olanzapine showed superior effects in the delayed phase, which might be due to the low incidence of emesis and nausea during the acute phase. Most of the acute cases of CINV can be addressed by doctors, as they usually occur in hospitals; therefore, delayed CINV is the patients' major concern after chemotherapy because it usually occurs at home and may result in admissions to the emergency room. Our meta-analysis showed that olanzapine is effective at controlling nausea and vomiting in the delayed phase of chemotherapy and may be considered a choice for oncologists. In addition, for patients receiving multiple-day chemotherapy or highdose chemotherapy with stem cell transplantation, the current recommendation is to administer a first-generation 5-HT3 receptor antagonist and dexamethasone daily during each day of chemotherapy $^{3}$, which appeared to be less effective at controlling delayed $\mathrm{CINV}^{21}$. Further studies may be designed to evaluate olanzapine's effect in these treatment strategies.

Many doctors may worry about the side effects of olanzapine because it was originally used as an atypical antipsychotic agent. In Navari's study ${ }^{10}$, the maximum tolerated dose of olanzapine $(10 \mathrm{mg} /$ d) was used, and no significant changes between the olanzapine containing regimen and the standard regimen were observed for any of the symptom scores. However, when the same dose was used in the Chinese population, $\operatorname{Tan}^{11}$ observed that $73 \%$ of patients in the test group had sleepiness during chemotherapy. Further study may be needed to determine the best dose of olanzapine for different races. The other side effects of olanzapine, such as sedation and weight gain $^{22}$, may not be concerns for patients undergoing chemotherapy.

Thus, olanzapine has been shown to be a safe and effective agent for the prevention of CINV, especially in the delayed phase; it is also a 
A

OL Control

Odds Ratio

Odds Ratio

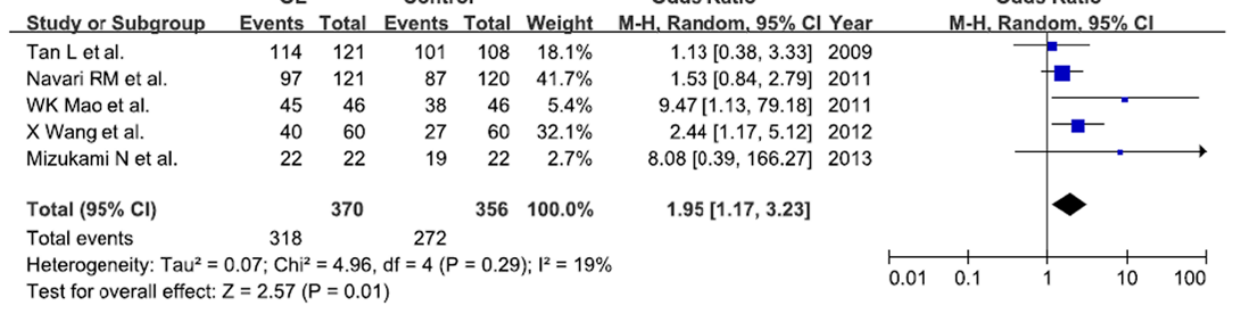

B

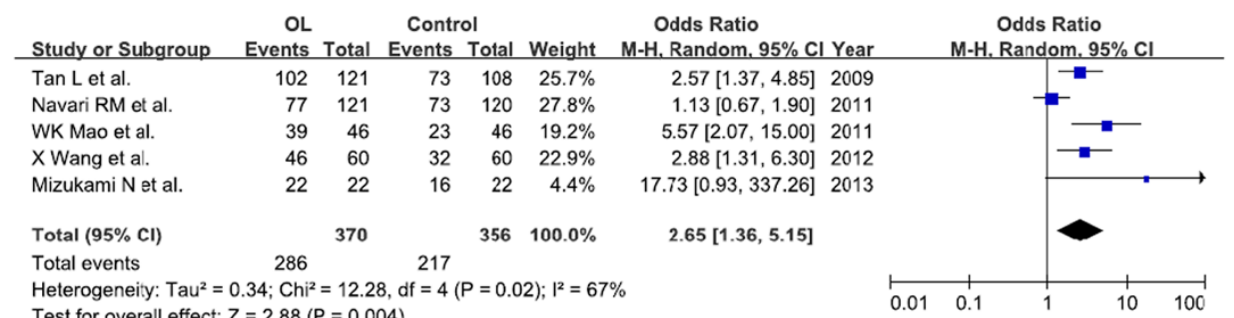

Test for overall effect: $Z=2.88(P=0.004)$

C

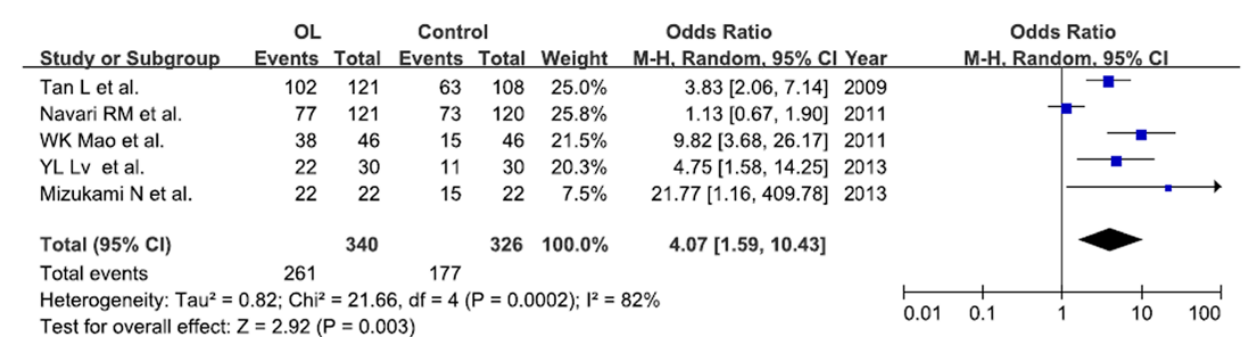

Figure $2 \mid$ Relative Risk of Complete Response.

A

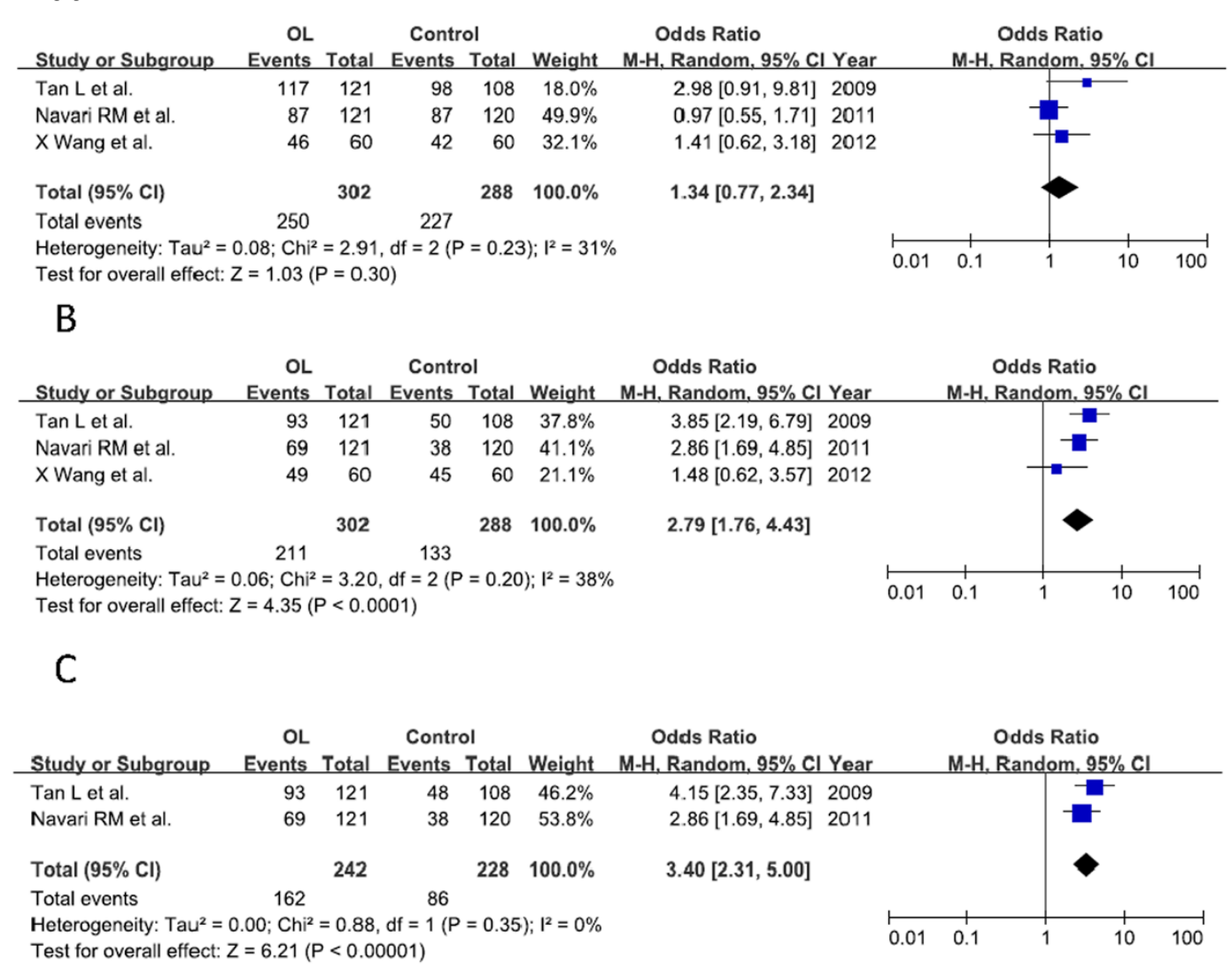

Figure 3 Relative Risk of nausea control. 


\begin{tabular}{|c|c|c|c|c|c|c|c|c|c|}
\hline Control & Period & $\begin{array}{l}\text { Overall or } \\
\text { subgroup }\end{array}$ & $\begin{array}{c}\text { Study } \\
\text { number (N) }\end{array}$ & $\begin{array}{l}\text { Participant } \\
\text { (N) }\end{array}$ & OR (95\%Cl) & Z & $P$ & $P^{2}(\%)$ & $\mathrm{P}_{\text {het }}$ \\
\hline \multirow[t]{9}{*}{ Vomiting control } & \multirow[t]{3}{*}{ Acute } & ALL & 5 & 726 & $1.95(1.17-3.23)$ & 2.57 & 0.01 & 19 & 0.29 \\
\hline & & Chinese & 3 & 441 & $2.24(0.94-5.33)$ & 1.82 & 0.07 & 41 & 0.18 \\
\hline & & $\begin{array}{l}\text { All excluding } \\
\text { different criteria }\end{array}$ & 4 & 485 & $2.39(1.10-5.22)$ & 2.19 & 0.03 & 27 & 0.25 \\
\hline & \multirow[t]{3}{*}{ Delayed } & AlL & 5 & 726 & $2.65(1.36-5.15)$ & 2.88 & 0.004 & 67 & 0.02 \\
\hline & & Chinese & 3 & 441 & $3.11(2.00-4.83)$ & 5.03 & 0.00001 & 0 & 0.42 \\
\hline & & $\begin{array}{l}\text { All excluding } \\
\text { different criteria }\end{array}$ & 4 & 485 & $3.24(2.08-5.04)$ & 5.20 & 0.00001 & 2 & 0.38 \\
\hline & \multirow[t]{3}{*}{ Overall } & ALL & 5 & 666 & $4.07(1.59-10.43)$ & 2.92 & 0.003 & 82 & 0.0002 \\
\hline & & Chinese & 3 & 381 & $5.15(2.96-8.96)$ & 5.79 & 0.00001 & 21 & 0.28 \\
\hline & & $\begin{array}{l}\text { All excluding } \\
\text { different criteria }\end{array}$ & 4 & 425 & $5.38(3.14-9.20)$ & 6.14 & 0.00001 & 14 & 0.32 \\
\hline \multirow[t]{7}{*}{ Nausea control } & \multirow{3}{*}{ Acute } & ALL & 3 & 590 & $1.34(0.77-2.34)$ & 1.03 & 0.30 & 31 & 0.23 \\
\hline & & Chinese & 2 & 349 & $1.80(0.90-3.59)$ & 1.67 & 0.10 & 4 & 0.31 \\
\hline & & $\begin{array}{l}\text { All excluding } \\
\text { different criteria }\end{array}$ & 2 & 349 & $1.80(0.90-3.59)$ & 1.67 & 0.10 & 4 & 0.31 \\
\hline & \multirow[t]{3}{*}{ Delayed } & ALL & 3 & 590 & $2.79(1.76-4.43)$ & 4.35 & 0.0001 & 38 & 0.20 \\
\hline & & Chinese & 2 & 349 & $2.54(1.01-6.42)$ & 1.97 & 0.05 & 69 & 0.07 \\
\hline & & $\begin{array}{l}\text { All excluding } \\
\text { different criteria }\end{array}$ & 2 & 349 & $2.54(1.01-6.42)$ & 1.97 & 0.05 & 69 & 0.07 \\
\hline & Overall & ALL & 2 & 470 & $3.40(2.31-5.00)$ & 6.21 & 0.00001 & 0 & 0.35 \\
\hline
\end{tabular}

highly cost-effective drug compared with 5-HT3-serotonin antagonists and NK1-antagonists. We have reasons to believe that olanzapine is a good choice for prophylactic treatment in patients receiving highly to moderately emetogenic chemotherapy. Further studies may determine not only which combinations of agents with different mechanisms will be the most beneficial for patients but also the clinical characteristics of the patient groups to achieve so called "personalised therapy".

\section{Methods}

The Medline (Ovid), PubMed, CNKI, Wanfang, and Weipu databases were used to search for electronic publications that were published from 1990 to October, 2013. The keywords included "olanzapine" and "CINV" or "chemotherapy-induced nausea and vomiting or "nausea" or "vomiting". If there were multiple publications from the same study group, the most complete and recent results were used. The search results were limited to articles published in English or Chinese and studies performed in humans. We did not restrict our selections based on the countries in which the studies were performed. To avoid selection bias, no study was rejected because of poor quality scores.

Ethics. The study protocol was approved by the Coordinating Ethics Committee of Ruijin Hospital, and the study methods were carried out in accordance with the approved guidelines.

Inclusion/exclusion criteria. Case control studies were included in this metaanalysis, regardless of sample size. The outcome was complete response (CR) of the acute, delayed, and overall phases of CINV after chemotherapy. CR was defined as no emetic episodes and no rescue medication. The overall phase was defined as $0-$ 120 hours after chemotherapy.

Data extraction. Two reviewers (X.F.W. and Y.F.) independently assessed all potentially relevant studies and reached a consensus on all items. In case of disagreement, a third author provided an assessment. The following data were collected from each study: first author, year of publication, ethnicity, study design, baseline characteristics of the study population, total number of cases and controls, and emesis/nausea distribution in cases and controls. After data extraction, discrepancies were adjudicated by discussion until a consensus was reached.

Statistical methods. The meta-analysis was conducted using Review Manager software (version 5.0.19). Odds ratios (OR) and $95 \%$ confidence intervals (CI) were calculated. A heterogeneity test $p>.05$ was interpreted as signifying a low level of heterogeneity suitable for meta-analysis. We also performed subgroup analyses in Chinese patients.

1. Bloechl-Daum, B., Deuson, R. R., Mavros, P., Hansen, M. \& Herrstedt, J. Delayed nausea and vomiting continue to reduce patients' quality of life after highly and moderately emetogenic chemotherapy despite antiemetic treatment. J Clin Oncol. 24, 4472-4478(2006).

2. Osoba, D. et al. Effect of postchemotherapy nausea and vomiting on healthrelated quality of life. The Quality of Life and Symptom Control Committees of the National Cancer Institute of Canada Clinical Trials Group. Support Care Cancer. 5, 307-333(1997).

3. Ettinger, D. S. et al. Antiemesis. J Natl Compr Canc Netw. 10, 456-485(2012).

4. Hesketh, P. J. Chemotherapy-induced nausea and vomiting. N Engl J Med. 358, 2482-2494(2008).

5. Herrstedt, J. \& Dombernowsky, P. Anti-emetic therapy in cancer chemotherapy: current status. Basic Clin Pharmacol Toxicol. 101, 143-150(2007).

6. Fulton, B. \& Goa, K. L. Olanzapine: are view of its pharmacological properties and therapeutic efficacy in the management of schizophrenia and related psychoses. Drugs. 53, 281-298(1997).

7. Bymaster, F. P. et al. Radioreceptor binding profile of the atypic alantipsychotic olanzapine. Neuropsychopharmacology. 14, 87-96(1996).

8. Khojainova, N., Santiago-Palma, J., Kornick, C., Breitbart, W. \& Gonzales, G. R. Olanzapine in the management of cancer pain. J.Pain Symptom Manage. 23, 546-550(2002).

9. Mizukami, N. et al. Olanzapine for the prevention of chemotherapy-induced nausea and vomiting in patients receiving highly or moderately emetogenic chemotherapy: a randomized, double-blind, placebo-controlled study. J. Pain Symptom Manage. 47, 542-550(2014).

10. Navari, R. M., Gray, S. E. \& Kerr, A. C. Olanzapine versus aprepitant for the prevention of chemotherapy-induced nausea and vomiting: a randomized phase III trial. J Support Oncol. 9, 188-195(2011).

11. Tan, L. et al. Clinical research of Olanzapine for prevention of chemotherapyinduced nausea and vomiting. J Exp Clin Cancer Res. 28, 131(2009).

12. Wang, X. \& Wang, L. Effectiveness of olanzapine in prevention of chemotherapyinduced nausea and vomiting. Clin J Clinicians (Electronic Edition). 6, 7406-7407(2012).

13. Mao, W. K. \& Peng, L. Clinical observation of Olanzapine combined with Granisetrom and Hexadecadrol prevent nausea vomit induced by chemoradiontherapy. Chinese Journal of Medicine Guide. 13, 452-454(2011).

14. Lu, Y. L. et al. Antiemetic effect of low dose olanzapine in solid tumor chemotherapy. Clin J Cancer Prev Treat. 20, 544-554(2013).

15. Jackson, W. C. \& Tavernier, L. Olanzapine for intractable nausea in palliative care patients. J. Palliative Med. 6, 251-255(2003).

16. Licup, N. Olanzapine for nausea and vomiting. Am J Hosp Palliat Care. 27, 432-434(2010).

17. Pirl, W. F. \& Roth, A. J. Remission of chemotherapy-induced emesis with concurrent olanzapine treatment: a case report. Psychooncology. 9, 84-87(2010).

18. Jackson, W. C. \& Tavernier, L. Olanzapine for intractable nausea in palliative care patients. J. Palliative Med. 6, 251-255 (2003).

19. Passik, S. D. et al. A pilot exploration of the antiemetic activity of olanzapine for the relief of nausea in patients with advanced pain and cancer. J. Pain Symptom Manage. 2, 526-532(2002). 
20. Passik, S. D. et al. A phase I trial of olanzapine for the prevention of delayed emesis in cancer patients receiving chemotherapy. Cancer Invest. 22, 383-388(2004).

21. Navari, R. M. Prevention of emesis from multiple-day chemotherapy regimens. J Nat Compr Cancer Netw. 5, 51-59(2007).

22. Allison, D. B. \& Casey, D. E. Antipsychotic-induced weight gain: a review of the literature. J Clin Psychiatry. 62, 22-31(2001).

\section{Author contributions}

Data collection: X.F.W.; statistical analysis: Y.F.; manuscript writing and editing: X.F.W., Y.C., B.L.G. and B.H.H. All of the authors have seen and approved the final version of the manuscript.

\section{Additional information}

Competing financial interests: The authors declare no competing financial interests.

How to cite this article: Wang, X.-f., Feng, Y., Chen, Y., Gao, B.L. \& Han, B.-H. A

meta-analysis of olanzapine for the prevention of chemotherapy-induced nausea and vomiting. Sci. Rep. 4, 4813; DOI:10.1038/srep04813 (2014).

(c) (i) $\Theta$ This work is licensed under a Creative Commons Attribution-NonCommercialNoDerivs 3.0 Unported License. The images in this article are included in the article's Creative Commons license, unless indicated otherwise in the image credit if the image is not included under the Creative Commons license, users will need to obtain permission from the license holder in order to reproduce the image. To view a copy of this license, visit http://creativecommons.org/licenses/by-nc-nd/3.0/ 